\title{
Correlation between body weight before slaughter and slaughter yields broiler carcasses of different lines
}

\author{
Tatjana Pandurević, Miroslav Lalović \\ University of East Sarajevo, Faculty of Agriculture, Vuk Karadzic 30, \\ East Sarajevo, Bosnia and Herzegovina (RS) \\ Sreten Mitrović \\ University of Belgrade, Faculty of Agriculture, Institute of Zootechnic, \\ Nemanjina 6, 11080 Zemun, Republic of Serbia
}

\begin{abstract}
The aim of this study was to determine the strength of the correlation of phenotypic correlation between body weight before slaughter and meat yield (slaughter yields) chickens two hybrids (Coob 500 and Hubbard) at different ages which is closely related to the current demand in the market of Bosnia and Herzegovina (RS) and the environment and whether consumers are interested in one - portion "chicken" or prefabricated meats.

The determined data in this paper are to some extent are reaching the conclusion to which the period reasonably imaginative broiler chickens of Cobb 500, Hubbard or in relation to the fact that the hybrid show more fattening and carcass value.

Key words: phenotypic correlations, body weight before slaughter, slaughter yields, Coob 500, Hubbard
\end{abstract}




\section{Introduction}

If you observe the general population, then poultry, as well as cheaper, becomes the main interested consumers. Due to technical and technological achievements in the production of broiler meat, and biological characteristics of poultry, there is a steady trend of growth of production in the world and our country.

The aim of broiler breeding is the production of broiler carcasses of acceptable quality for the consumer. What will be the acceptability depends on the quality and quantity of muscle mass in the hulls. So, for the meat industry, it is essential that fattened chickens have good yields, the preferred conformation of the optimal schedule of adipose tissue, the appropriate color and the less damage during transport to the slaughterhouse.

Consumers, however, insist on the highest quality meat, and it is anticipated that in the near future marketing of poultry products solely depend on their quality, Tolimir (2006).

The aim is to determine the strength of the correlation of phenotypic correlation between body weight before slaughter and meat yield (dressing percentages) chickens two lines (Cobb 500 and Hubbard) in a different age, which is closely linked to the current demand at the market of Bosnia and Herzegovina (RS) and the environment, and whether consumers are interested in jednoporcijskim "chicken" or konfekcionisanim meat.

Fortified indicators (results) will to some extent enable a conclusion to what period is justified toviti broiler chickens of Cobb 500, respectively Hubbard in relation to that hybrid will show better (cheaper) fattening and carcass value.

\section{Material and Method}

According to the regulations on the quality of poultry meat ("Off. Gazette of SFRY", no. 1/81 and 51/88), in relation to methods of processing, carcasses of slaughtered poultry can be marketed as: classic processed, prepared and ready for baking barbecue.

On the 35th (both genotypes) and 40 (Hubbard) or 42 days (Cobb 500) ages, a random sample were singled out for slaughter chickens from each treatment. In order to determine the yield of carcasses or slaughter yields of each treatment is selected, 20 male and 20 female chickens.

Phenotypic correlation coefficient to measure the strength of correlations between the two observed variable.

Correlation coefficient, we compared the individual values in the test. Simple correlation is made between the following characteristics: carcass weight before slaughter and slaughter yields in both genotypes, for both sexes and 
collectively by the poles, at the age of 35 days, carcass weight before slaughter and slaughter yields, for both sexes and collectively by the poles, at the age of 40 days (Hubbard) or 42 days (Cobb 500).

Phenotypic correlation coefficient is calculated using the formula by Hadživuković (1991). The severity of the phenotypic correlation coefficient is discussed on the basis of Roemer- Orphalove classification. Testing the statistical significance of the obtained correlation coefficients was done by t-test.

\section{Results and discussion}

Test results of the correlation relationship between body weight before slaughter and slaughter yields hulls, at the age of 35 (both genotypes), then 40 (Hubbard) and 42 (Cobb 500) days, as well as the analysis of the established correlation coefficients, and the results of tests of their significance, are shown in table 1 and 2.

Correlation coefficients were calculated for yields "standard treatment", marked as $\mathrm{rxy}_{1}$, then the yields "ready to roast" $\mathrm{rxy}_{2}$ and eventually yields to "grill ready" rxy.

Table 1: The correlation between between weight before slaughter and slaughter yields of broiler chickens of Cobb 500 and Hubbard (35 day)

\begin{tabular}{|c|c|c|c|c|c|c|c|}
\hline \multirow[t]{2}{*}{ Hybrid } & \multirow{2}{*}{$\begin{array}{c}\text { Gende } \\
\mathrm{r}\end{array}$} & \multicolumn{3}{|c|}{ Correlation coefficients } & \multicolumn{3}{|c|}{$t_{\text {exp. }}$} \\
\hline & & $r_{x y 1}$ & $r_{x y 2}$ & $r_{x y 3}$ & $r_{x y 1}$ & $r_{\mathrm{xy} 2}$ & $\mathrm{r}_{\mathrm{xy} 3}$ \\
\hline \multirow{6}{*}{$\begin{array}{c}\text { Cobb } \\
500\end{array}$} & $\pi$ & $0,700 * *$ & $0,802 * *$ & $0,686 * *$ & 4,16 & 5,68 & 3,98 \\
\hline & o & $*$ & * & $*$ & 7 & 8 & 8 \\
\hline & $\delta^{+}+q$ & $0,898 * *$ & $0,776^{* *}$ & $0,754 * *$ & 8,71 & 5,20 & 4,86 \\
\hline & & $*$ & $*$ & $*$ & 8 & 8 & 5 \\
\hline & & $0,768 * *$ & $0,785^{* *}$ & $0,710 * *$ & 7,38 & 7,85 & 6,17 \\
\hline & & $*$ & $*$ & * & 5 & 0 & 4 \\
\hline \multirow{6}{*}{ Hubbard } & $\hat{0}$ & $0,793^{* *}$ & $0,732 * *$ & $0,565 * *$ & 5,54 & 4,54 & 2,91 \\
\hline & q & $*$ & $*$ & & 5 & 7 & 2 \\
\hline & $\delta+q$ & $0,722 * *$ & $0,767^{* *}$ & $0,725 * *$ & 4,42 & 5,07 & 4,47 \\
\hline & & $*$ & $*$ & $*$ & 9 & 9 & 5 \\
\hline & & $0,010^{\mathrm{NS}}$ & $0,276^{\mathrm{NS}}$ & $-0,092^{\mathrm{NS}}$ & 0,06 & 1,77 & 0,57 \\
\hline & & & & & 2 & 0 & 1 \\
\hline
\end{tabular}

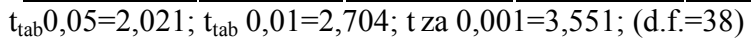

$\mathrm{t}_{\mathrm{tab}} 0,05=2,000 ; \mathrm{t}_{\mathrm{tab}} 0,01=2,660 ; \mathrm{t}_{\mathrm{tab}} 0,001=3,460 ;($ d.f. $=78)$

N.S. - $\mathrm{P}>0,05 ; *$ - $\mathrm{P}<0,05 ; * *$ - $\mathrm{P}<0,01 ; * * *-\mathrm{P}<0,001$

Based on the data from Table 1, first note that between body weight before slaughter and dressing percentage ("standard treatment" and "ready to 
roast"), at the Cobb 500, in both sexes (individually and collectively) hybrids were established very strong correlation connection which are statistically confirmed or highly significant $(\mathrm{P}<0.001)$. Also, at the Cobb 500, between body weight before slaughter and yield "grill ready", with females there was a high correlation, while in males and both sexes (collectively) established a strong correlation, and all showed a statistically high significance $(\mathrm{P}<0.001)$.

When Hubbard, between body weight before slaughter and dressing percentage "standard treatment" in males was found a very strong correlation, while the females connection was strong. According to the statistical significance of both correlation coefficients were highly significant $(\mathrm{P}<0.001)$. The absence of correlations and statistical significance $(\mathrm{P}>0.05)$ was found between body weight before slaughter and dressing percentage "standard treatment" genotype Hubbard, in both sexes (sum).

Between body weight before slaughter and dressing percentage "ready to roast" line hybrid Hubbard, with females, a very strong, while males had a strong connection. According to the statistical significance of both correlation coefficients were highly significant $(\mathrm{P}<0.001)$. Unlike these previous two correlation coefficients, with Hubbard, viewed collectively by genders, a weak dependence, the significance of which is absent $(\mathrm{P}>0.05)$.

When Hubbard, between body weight before slaughter and yield "grill ready", both male and female heads the association was strong, statistically $(\mathrm{P}<0.01)$ and higher $(\mathrm{P}<0.001)$ significant. The absence of correlations and statistical significance $(\mathrm{P}>0.05)$ was found between body weight before slaughter and dressing percentage "standard treatment" genotype Hubbard, in both sexes (sum). In addition, this correlation is direction, unlike previous was negative.

The strongest correlation was between body weight before slaughter and dressing percentage "standard treatment" $\left(\mathrm{rxy}_{1}=0.898\right)$ in females Cobb 500th

Results in table 2 show that between body weight before slaughter and dressing percentage "standard treatment" at the Cobb 500, both male and female heads there was a strong correlation, statistically $(\mathrm{P}<0.01)$ and higher $(\mathrm{P}<0.001)$ significant while for both sexes (collectively) the correlation was moderate, statistically highly significant $(\mathrm{P}<0.01)$.

Correlation dependence, with Cobb 500, which is found between body weight before slaughter and dressing percentage "ready to roast" for females and collectively, was strong, while for males was very strong. The statistical significance of all three of the correlation coefficient was confirmed as highly significant $(\mathrm{P}<0.001)$. Also, at the Cobb 500, between body weight before slaughter and yield "grill ready", in males there was a high correlation, while in both sexes (sum), the median, and both showed statistical significance, as a $(\mathrm{P}<0.01)$ and higher $(\mathrm{P}<0.001)$ significant. Women's throat Cobb 500 had a weak 
correlation between the observed properties, which was not statistically significant $(\mathrm{P}>0.05)$.

Table 2. The correlation between between weight before slaughter and slaughter yields of broiler chickens of Cobb 500 and Hubbard (35 day)

\begin{tabular}{|c|c|c|c|c|c|c|c|}
\hline \multirow{2}{*}{ Hybrid } & \multirow{2}{*}{$\begin{array}{c}\text { Gende } \\
\mathrm{r}\end{array}$} & \multicolumn{3}{|c|}{ Correlation coefficients } & \multicolumn{3}{|c|}{$t_{\text {exp. }}$} \\
\hline & & $\mathrm{r}_{\mathrm{xy} 1}$ & $\mathrm{r}_{\mathrm{xy} 2}$ & $\mathrm{r}_{\mathrm{xy} 3}$ & $r_{x y 1}$ & $\mathrm{r}_{\mathrm{xy} 2}$ & $r_{x y 3}$ \\
\hline \multirow{5}{*}{$\begin{array}{c}\text { Cobb } \\
500\end{array}$} & \multirow{5}{*}{$\begin{array}{c}\hat{0} \\
\phi \\
+ \\
0^{\lambda}+q\end{array}$} & $0632 * *$ & $0,725^{* *}$ & $0,858 * *$ & 3,45 & 4,47 & 7,15 \\
\hline & & $0,635 \cdots$ & $*$ & $*$ & 9 & 5 & 0 \\
\hline & & $0,749^{* *}$ & $0,887 * *$ & $0.177^{\mathrm{NS}}$ & 4,80 & 8,21 & 0,76 \\
\hline & & & $*$ & & 1 & 3 & 3 \\
\hline & & $0,456^{* *}$ & $0,649^{* *}$ & $0,424 * *$ & 3,16 & 5,23 & 2,88 \\
\hline \multirow{6}{*}{ Hubbard } & \multirow{6}{*}{$\begin{array}{c}\hat{0} \\
0 \\
+ \\
\hat{0}+q\end{array}$} & $0.656^{* *}$ & $0.652 * *$ & $0.678 * *$ & 3.68 & 3.66 & 391 \\
\hline & & $*$ & $*$ & $*$ & 5 & 3 & 9 \\
\hline & & $0,650^{* *}$ & $0,812^{* *}$ & $0,693 * *$ & 3,61 & 5,92 & 4,07 \\
\hline & & $*$ & $*$ & $*$ & 1 & 7 & 6 \\
\hline & & $-0.194^{\mathrm{NS}}$ & $0.161^{\mathrm{NS}}$ & $0005^{\mathrm{NS}}$ & 1,21 & 1,00 & 0,03 \\
\hline & & $-0,194$ & 0,161 & 0,005 & 3 & 6 & 1 \\
\hline
\end{tabular}

$\mathrm{t}_{\text {tab }} \overline{0,05=2,021 ;} \mathrm{t}_{\text {tab }} 0,01=2,704 ; \mathrm{t} \mathrm{za} 0,001=3,551 ;(\mathrm{d} . \mathrm{f} .=38)$

$\mathrm{t}_{\text {tab }} 0,05=2,000 ; \mathrm{t}_{\mathrm{tab}} 0,01=2,660 ; \mathrm{t}_{\mathrm{tab}} 0,001=3,460 ;(\mathrm{d} . \mathrm{f} .=78)$

N.S. - $\mathrm{P}>0,05 ; *$ - $\mathrm{P}<0,05 ; * *-\mathrm{P}<0,01 ; * * *-\mathrm{P}<0,001$

When Hubbard, between body weight before slaughter and dressing percentage "standard treatment", both male and females was found a strong correlation, statistically highly significant $(\mathrm{P}<0.001)$. Very weak correlation was found between body weight before slaughter and dressing percentage "standard treatment" genotype Hubbard, in both sexes (sum), which was not statistically significant $(\mathrm{P}>0.05)$. In addition, this correlation is a negative direction.

Furthermore, between body weight before slaughter and dressing percentage "ready to roast," both male and females established a strong and very strong correlation, statistically highly significant $(\mathrm{P}<0.001)$, whereas in both sexes (total) correlation was very weak, not statistically significant $(\mathrm{P}>0.05)$. For both sexes (collectively) is determined by the absence of correlations and statistical significance $(\mathrm{P}>0.05)$. The strongest correlation was between body weight before slaughter and slate 'ready to roast' $\left(\mathrm{rxy}_{2}=0.887\right)$ in females Cobb 500th.

Research within this issue are very little was done in broilers, much more with other types of livestock. Peric and Mitrovic (1989) with three various genotypes turkeys, found a very strong or complete dependence correlation between body weight and carcass yield with the difference that the authors accounted for the results in absolute values. 


\section{Conclusion}

Based on the test results of the correlation relationship between body weight before slaughter and slaughter yields hulls, at the age of 35 days, or 40 (Hubbard), and 42 (Cobb 500) days, we can conclude the following:

Between the carcass weight before slaughter and slaughter yields, at the age of 35 days, with Cobb 500 there is a positive correlation, as in Hubbard, provided that at Hubbard (summary) noted the lack of statistical significance, and negatively correlated between the carcass before slaughter and slaughter yields "grill ready".

Between the carcass weight before slaughter and slaughter yields, at the age of 40. (Hubbard) and 42 (Cobb 500) days, there was a positive correlation with the Cobb 500 as in Hubbard, provided that at Hubbard (collectively) found no statistical significance, as well as a negative correlation between carcass weight before slaughter and slaughter yields "standard treatment".

Generally, the spaces H (RS) market requirements are directed by the high demand for "jednoporcijskim" chicken and the meat konfekcionisanim, which resulted in the definition of the different duration of this in our work. By determining the correlation relationship between the individual fattening and slaughter traits, defining the correlation coefficients and the significance thereof, gave some contribution in determining the potential of the genotypes, or the profitability of the length of it.

\section{References}

Hadživuković S . (1991). Statistical methods with application in agricultural and biological research, p. 461, Novi Sad.

Peric V. Mitrovic S. (1989). Simple correlation between the weight of carcass and weights of basic parts ućuraka different hybrid lines. Poultry, 11-12,348-349.

Regulations on the quality of poultry meat. Official Gazette of the SFRY no. 1, January 1981, 13-14.

Tolimir N. (2006). The technology of growing broilers and trends in the production of chicken meat. Application of modern technologies in poultry. Institute of Applied Science in Agriculture, p. 22-27, Belgrade. 


\title{
KORELACIONA POVEZANOST IZMEĐU TJELESNE MASE PRIJE KLANJA I KLANIČNIH RANDMANA TRUPOVA BROJLERSKIH PILIĆA RAZLIČITIH PROVENIJENCI
}

\author{
- originalan naučni rad- \\ T. Pandurević, M. Lalović \\ Univerzitet u Istočnom Sarajevu, Poljoprivredni fakultet, \\ Vuka Karadžića 30,Istočno Sarajevo, RS, BiH \\ S. Mitrović \\ Univerzitet u Beogradu, Poljoprivredni fakultet, Institut za zootehniku, \\ Nemanjina 6, 11080 Zemun, Srbija

\section{Rezime} \\ Cilj ovog rada je da se utvrdi jačina fenotipske korelacione povezanosti \\ između tjelesne mase prije klanja i prinosa mesa (klanični randmani) pilića dvije \\ provenijence (Coob 500 i Hubbard) u različitom uzrastu što je usko povezano sa \\ trenutnom potražnjom na tržištu $\mathrm{BiH}(\mathrm{RS})$ i okoline, odnosno da li su potrošači \\ zainteresovani za jednoporcijskim ,piletom“ ili konfekcionisanim mesom. \\ Utvrđeni pokazatelji u radu su u određenoj mjeri omogućili donošenje \\ zaključka do kog je perioda opravdano toviti brojlerske piliće hibrida Cobb 500, \\ odnosno Hubbard u odnosu na činjenicu koji će hibrid pokazati bolje tovne i
} klanične vrijednosti.

Ključne reči: fenotipska korelacija, tjelesna masa prije klanja, klanični randmani, Coob 500, Hubbard 